Penelitian ...

\title{
DESAIN AKTIVITAS PEMBELAJARAN UNTUK MENGEMBANGKAN KECERDASAN LOGIK-MATEMATIK ANAK USIA DINI
}

\author{
Muhammad Yaumi \& Sitti Fatimah S.Sirate \\ e-mail: muhammadyaumi@yahoo.com \\ Fakultas Tarbiyah dan Keguruan UIN Alauddin Makassar
}

\begin{abstract}
Abstrak: Tujuan studi ini adalah untuk memperbaiki desain aktivitas pembelajaran, mengembangkan jenis aktivitas dan mengintegrasikan komponen desain ke dalam aktivitas pembelajaran yang dapat mengembangkan kecerdasan logik-matematik anak usia dini. Penelitian ini dilakukan mulai pada bulan Januari sampai dengan Agustus 2014. Metode penelitian adalah penelitian tindakan kolaboratif dengan melibatkan 30 responden/ informan, 5 orang pengawas dan 10 orang kepala sekolah sebagai kolaborator. Metode pengumpulan data menggunakan observasi, forum group discussion, studi dokumen, angket, dan tes dengan menggunakan teknik analisis data kualtitatif dan kuantitatif. Hasil penelitian menunjukkan bahwa desain aktivitas pembelajaran telah mendorong pendidik untuk menerapkan survei kecerdasan logik-matematik, menerapkan delapan jenis aktivitas pembelajaran, dan memperbaiki kemampuan pendidik dalam mengintegrasikan komponen desain. Peserta didik menjadi berkembang sesuai dengan bakat, talenta dan minat mereka.
\end{abstract}

Kata kunci: desain pembelajaran, kecerdasan logik-matematik, aktivitas belajar

\section{INSTRUCTIONAL ACTIVITY DESIGN TO DEVELOP LOGIC-MATHEMATIC INTELLIGENCE OF EARLY-AGED CHILDREN}

\begin{abstract}
The purpose of this study is to improve instructional activity desain, develop the kinds of activity, and integrate design components to instructional activities which can develop logic-mathematic intelligence of early-aged children. The study was conducted as from January through August 2014 employing colaborative action research method and involving 30 respondents/informen, 5 school supervisors, and 10 principals as collaborators. The data were collected using observation technique, group discussion, document study, quesionaire, and test to be analyzed quantitatively and qualitatively. The research findings show the instructional activity design has encouraged the teachers to conduct survey of logic-mathematic intelligence, implement 8 kinds of instructional activities, and improve teachers' competence in integrating design components. Learners develop on the basis of their intelligence, talent, and interest.
\end{abstract}

Keywords: instructional design, logic-mathematic intelligence, learning activities.

\section{PENDAHULUAN}

Identifikasi, ekplorasi, dan pendeteksian keluarbiasaan ganda yang dimiliki setiap anak belum banyak dilakukan baik oleh orang tua, lembaga pendidikan, apalagi oleh masyarakat di mana anak itu berkembang (Semiawan dan Mangunsong, 2010). Perkembangan intelektual anak cenderung berkolaborasi negatif dengan keinginan orang tua untuk menjadikan anak seperti orang yang mereka idolakan. Anak sering diarahkan pada sesuatu yang sebenarnya tidak bersinergi dengan minat, bakat, dan talenta yang dimiliki. Konsekuensinya, begitu banyak anak yang putus sekolah (drop out), frustasi, dan menjadi anak yang berperilaku menyimpang. Namun, tidak sedikit pula anak yang putus sekolah tetapi tetap menunjukkan keberhasilan yang luar biasa pada bidang yang mereka tekuni karena ditunjang oleh lingkungan yang membawa pada teraktualisasinya kecerdasan, sikap, dan perilaku yang baik (Yaumi, 2013).

Secara psikologis, intelektual anak berkembang melalui proses mental terstuktur yang dikenal dengan istilah asimilasi, akomodasi, dan adaptasi untuk membentuk schema (Piaget, 1965). Asimilasi adalah suatu proses pemerolehan informasi baru dan penyesuaian dengan pengetahuan sebelumnya tentang objek atau dunia, akomodasi berarti penyesuaian pengalaman baru dengan memperbaiki rencana sebelumnya untuk memperoleh informasi baru, dan 
adaptasi adalah proses mencari keseimbangan (ekuilibrasi) antara diri dan lingkungan untuk membentuk skema. Adapun skema adalah pola tindakan mental sederhana, suatu bentuk organisasi informasi yang digunakan seseorang untuk menginterpretasi sesuatu melalui panca indera (Singer dan Revenson, 1996: 15-18). Studi yang dilakukan sebelumnya tentang perkembangan intelektual anak dipelajari lebih mendalam oleh Mentossori yang kemudian membagi masa perkembangan ke dalam empat kategori; early childhood (masa awal anak-anak) yaitu umur antara 0-6 tahun, childhood (masa anak-anak) antara 6-12 tahun, adolescence (masa remaja) antara 12-18 tahun, dan maturity (kematangan) yakni antara umur 18-24 tahun (Feez, 2010: 26-28). Walaupun demikian, tingkat perkembangan anak menunjukkan hasil yang berbeda-beda tergantung dari sejauhmana aktualisasi kapasitas bawaan (inner capacity) dengan pengaruh lingkungan.

Itulah sebabnya Gardner dalam Musfiroh (2008) berpandangan bahwa tidak ada manusia yang tidak cerdas. Bahkan manusia bukan hanya memiliki tiga kecerdasan; logika-matematikaa, verbal-lingkuistik, dan visual-spasial seperti yang dikembangkan melalui teori Intellectual Question (IQ), melainkan juga kecerdasan jamak (multiple intelligences) yang mencakup delapan kecerdasan; kecerdasan verbal-linguistik, logika-matematikaa, visual-spasial, kinestetik-badaniyah, irama-musik, interpersonal, intrapersonal, dan naturalistik (Gardner, 1999 dan Amstrong, 2009), plus kecerdasan eksistensial-spiritual sebagai suatu kecerdasan yang masih dihipotesiskan karena bukti-bukti autentik belum dapat diterima sebagai hasil kajian empiris namun telah dijabarkan lebih jauh baik dalam hubungan dengan jenis teknologi yang digunakan (McKenzie, 2005) maupun dalam hubungannya dengan strategi pembelajaran berbasis multiple intelligences (Yaumi, 2013).

Kecerdasan logika-matematikaa merupakan salah satu bagian dari kecerdasan jamak yang merupakan kemampuan untuk mengkaji masalah, mengembangkan kemampuan mengoperasikan matematikaa secara logik dan analitik, dan melakukan investigasi ilmiah tentang berbagai hal (Visser, Ashton, dan Vernon, 2006). Studi yang berkenaan dengan kecerdasan logika-matematikaa dilakukan oleh Hanafin (2014) yang mengkaji tentang "Multiple Intelligences Theory, Action Research, and Teacher Professional Development: The Irish MI Project" dan salah satu temuannya menunjukkan bahwa kecerdasan logikamatematikaa dapat dibangun dengan pendekatan topik yang melibatkan proses penalaran deduktif atau melalui pertimbangan numerik. Kajian lain dilakukan oleh Supardi (2013) yang mengkaji tentang"The Contribution of Multiple Intelligence on Mathematics Learning's Success" menemukan bahwa terdapat tiga jenis kecerdasan yang dapat memberi dampak positif terhadap hasil belajar matematikaa termasuk (1) kecerdasan logika-matematikaa yang memberi dampak sebanyak 34,5\%, (2) visual-spasial sebesar $10,8 \%$, dan (3) kecerdasan interpersonal sebanyak $7,2 \%$. Studi yang lebih khusus pada kecerdasan logika-matematikaa dilakukan oleh Suhendri (2012) yang meneliti tentang "Pengaruh Kecerdasan logicmatematika, Rasa Percaya Diri, dan Kemandirian Belajar terhadap Hasil Belajar Matematikaa" dan salah satu temuannya menunjukkan bahwa terdapat pengaruh positif dan signifikan kecerdasan logikamatematikaa terhadap hasil belajar matematikaa. Begitu pula studi yang dilakukan oleh Niroo, Nejhad, dan Haghani (2012) yang mengkaji "The effect of Gardner theory application on mathematical/logical intelligence and student's mathematical functioning relationship" menunjukkan bahwa terdapat hubungan signifikan antara hasil tes (pre-test dan post-test) dengan kecerdasan logika-matematikaa. Hal ini menunjukkan bahwa adanya pengaruh positif antara hasil belajar dengan kemampuan logika-matematikaa.

Walaupun beberapa studi tentang kecerdasan jamak khususnya kecerdasan logika-matematikaa telah menemukan adanya dampak, pengaruh, dan hubungan antara prestasi belajar dengan kecerdasan logika-matematikaa, kesulitan dalam mendeteksi, mendesain, dan mengembangkan strategi pembelajaran untuk mengembangkan kecerdasan logika-matematikaa sangat dirasakan oleh guru Taman Kanak-Kanak (TK) dan Raudhatul Athfal (RA). Berdasarkan hasil studi pendahuluan tentang kondisi objektif pelaksanaan kecerdasan jamak dalam ruang kelas Anak usia dini di Kabupaten Gowa Sulawesi Selatan menunjukkan bahwa kecerdasan logikamatematikaa sangat sulit dikembangkan dengan beberapa alasan; (1) ketiadaan instrumen yang sesuai dengan kondisi real (nyata) masing-masing sekolah, (2) kesulitan dalam pemilihan aktivitas pembelajaran yang sesuai yang langsung dapat mengarahkan anak yang memiliki kecerdasan logikamatematikaa, (3) rendahnya pemahaman teori dan konsep tentang kecerdasan logika-matematikaa, dan (4) kurangnya referensi dan pelatihan yang berkenaan langsung dengan pentingnya memahami kecerdasan jamak peserta didik khususnya kecerdasan logikamatematikaa. Permasalahan tersebut telah berimbas pada pelaksanaan aktivitas pembelajaran yang 
sama sekali tidak berpijak pada kecerdasan logikamatematikaa walaupun beberapa guru telah mengikuti berbagai pelatihan yang diselenggarakan baik pada tingkat lokal maupun pada tingkat regional. Selain itu, guru tidak memahami jenis kecerdasan dari masingmasing peserta didik dan tidak dapat menentukan strategi untuk mengembangkan kecerdasan tersebut. Padahal pengembangan kecerdasan jamak termasuk kecerdasan logika-matematikaa telah dipercaya dapat memberi dampak positif pada prestasi belajar peserta didik, meningkatkan motivasi intrinsik, partisipasi, dan kepercayaan diri peserta didik, serta dapat membantu pendidik dalam mendesain pembelajaran berdasarkan kebutuhan peserta didik (Johnson, 2007).

Berpijak dari beberapa masalah yang dihadapi oleh pendidik khususnya guru TK/RA seperti dijabarkan di atas memberi inspirasi kepada peneliti untuk mengkaji lebih jauh tentang desain aktivitas pembelajaran untuk mengembangkan kecerdasan logika-matematikaa bagi anak usia dini. Hasil studi ini diharapkan dapat menjadi model aktivitas pembelajaran bagi guru TK/RA, acuan dalam pengembangan kurikulum, dan menambah khazanah keilmuan khususnya dalam kaitan dengan kecerdasan logika-matematikaa sebagai bagian dari kajian kecerdasan jamak.

Secara umum, aktivitas pembelajaran dipahami sebagai praktik-praktik yang memperlakukan peserta didik bukan hanya sebagai pelaksana pembelajaran melainkan juga berperan sebagai agen tindakan kognitif yang didistribusikan antara pendidik dan peserta didik (Yaumi, 2013). Dalam pengertian sederhana, aktivitas pembelajaran merujuk pada sistem pendidikan dalam memfasilitasi peserta didik untuk menjadi agen perubahan melalui pengalaman, pengetahuan, keterampilan, dan kemampuan yang dilakukannya sendiri serta memperoleh metode untuk belajar mandiri (Kozulin Gindis, Ageyev and Miller, 2003). Fondasi teori ini didasarkan pada teori Vygotsky tentang cultural historical theory, yang mengatakan bahwa pendidikan membawa dampak pada pengembangan. Dengan demikian, yang dimaksud dengan aktivitas pembelajaran adalah aktivitas atau kegiatan apa saja dari suatu individu yang dikelola dengan maksud untuk memperbaiki keterampilan, pengetahuan, dan kompetensi (European Commission, 2006).

Kecerdasan matematika adalah kemampuan yang berkenaan dengan rangkaian alasan, mengenal pola-pola dan aturan. Kecerdasan ini merujuk pada kemampuan untuk mengekplorasi pola-pola, kategorikategori dan hubungan dengan memanipulasi objek atau simbol untuk melakukan percobaan dengan cara yang terkontrol dan teratur (Kezar, 2001).
Kecerdasan matematika disebut juga kecerdasan logik dan penalaran karena merupakan dasar dalam memecahkan masalah dengan memahami prinsip-prisip yang mendasari sistem kausal atau dapat memanipulasi bilangan, kuantitas dan operasi (Yaumi, 2013). Kecerdasan logika-matematikaa berhubungan dengan angka-angka, pola, berpikir deduktif, induktif, dan rasional (Roop, Watson, dan Caldwell, 2001), kemampuan saintifik dan berpikir kritis (Alvis, dkk., 2008; Wilkens, 2006). Kecerdasan logika-matematikaa juga ditekankan pada kemampuan rasional, pengenalan pola abstrak, dan kemampuan untuk melakukan perhitungan yang kompleks (Motah, 2007).

Anak-anak yang memiliki kecerdasan logikamatematikaa yang tinggi sangat menyukai bermain dengan bilangan dan menghitung, suka untuk diatur, baik dalam problem-solving, mengenal pola-pola, menyukai permainan matematikaa, suka melakukan percobaan dengan cara yang logik, sangat teratur dalam tulis tangan, mempunyai kemampuan untuk berpikir abstrak, suka komputer, suka teka-teki, selalu ingin mengetahui bagaimana sesuatu itu berjalan, terarah dalam melakukan kegiatan yang berdasarkan aturan, tertarik pada pernyataan logik, suka mengumpulkan dan mengklasifikasi sesuatu, suka menyelesaikan berbagai persoalan yang membutuhkan penyelesaian yang logik, merasa lebih nyaman ketika sesuatu telah diukur, dibuat kategori, dianalisis, atau dihitung dan dijumlahkan, berpikir dengan konsep yang jelas, abstrak, tanpa katakata dan gambar. Penguatan dan pengembangan yang terarah terhadap kecerdasan matematika dapat mengarahkan karir seseorang menjadi guru matematikaa atau IPA yang memiliki kemampuan yang baik, ilmuan, insinyur, arsitek, programer komputer, pekerja konstruksi, analis anggaran, akuntan, perajut, dan aktivis yang relevan dengan ilmu-ilmu eksakta.

Pendidikan Anak Usia Dini (early childhood education) atau dalam bahasa Indonesia sering disingkat dengan PAUD menjadi suatu program yang sangat diminati belakangan ini, di samping telah menjadi trend (kecenderungan) yang mendunia juga keberpihakan pemerintah menunjukkan adanya kemauan politik yang menggembirakan bagi dunia pendidikan. Wikipedia (2014) memuat konsep anak usia dini yang merupakan tahapan awal dalam perkembangan manusia. Pada umumnya anak usia dini terdiri atas masa balita dan beberapa waktu setelahnya. Usia bermain adalah suatu sebutan yang tidak spesifik yang hampir mendekati lingkup anak usia dini. Beberapa periode perkembangan yang berkaitan 
dengan usia dan contoh interval yang ditetapkan adalah: bayi baru lahir (usia 0-5 minggu); bayi (usia 5 minggu - 1 tahun); balita (usia 1-4 tahun); anak prasekolah (usia 4-7 tahun); anak usia sekolah (usia 6-13 tahun); remaja (usia 13-19).

Istilah PAUD sering diberikan dengan nama yang berbeda-beda oleh beberapa lembaga. UNESCO menyebutnya sebagai Early Childhood Care and Education (ECCE), Pendidikan dan Perawatan Anak Usia Dini, Bank Dunia dan UNICEF menyebutnya sebagai early child development (ECD), Pengembangan Anak Usia Dini. Walaupun namanya sedikit berbeda, tetapi pandangan mereka tentang PAUD adalah sama yaitu pendidikan yang terjadi sebelum usia wajib belajar yang dilakukan dengan berbagai bentuk seperti penitipan anak, penitipan bayi, pusat perawatan anak, taman kanak-kanak, pra-sekolah dan lembaga yang sejenis lainnya. $\mathrm{Di}$ Indonesia, PAUD merujuk pada Taman Bermain Anak, Penitipan Anak, Taman kanak-Kanak atau Raudhatul Athfal.

Identifikasi, ekplorasi, dan pendeteksian keluarbiasaan ganda yang dimiliki setiap anak belum banyak dilakukan baik oleh orang tua, lembaga pendidikan, apalagi oleh masyarakat di mana anak itu berkembang (Semiawan dan Mangunsong, 2010). Perkembangan intelektual anak cenderung berkolaborasi negatif dengan keinginan orang tua untuk menjadikan anak seperti orang yang mereka idolakan. Anak sering diarahkan pada sesuatu yang sebenarnya tidak bersinergi dengan minat, bakat, dan talenta yang dimiliki. Konsekuensinya, begitu banyak anak yang putus sekolah (drop out), frustasi, dan menjadi anak yang berperilaku menyimpang. Namun, tidak sedikit pula anak yang putus sekolah tetapi tetap menunjukkan keberhasilan yang luar biasa pada bidang yang mereka tekuni karena ditunjang oleh lingkungan yang membawa pada teraktualisasinya kecerdasan, sikap, dan perilaku yang baik (Yaumi, 2013).

Secara psikologis, intelektual anak berkembang melalui proses mental terstuktur yang dikenal dengan istilah asimilasi, akomodasi, dan adaptasi untuk membentuk schema (Piaget, 1965). Asimilasi adalah suatu proses pemerolehan informasi baru dan penyesuaian dengan pengetahuan sebelumnya tentang objek atau dunia, akomodasi berarti penyesuaian pengalaman baru dengan memperbaiki rencana sebelumnya untuk memperoleh informasi baru, dan adaptasi adalah proses mencari keseimbangan (ekuilibrasi) antara diri dan lingkungan untuk membentuk skema. Adapun skema adalah pola tindakan mental sederhana, suatu bentuk organisasi informasi yang digunakan seseorang untuk menginterpretasi sesuatu melalui panca indera (Singer dan Revenson, 1996: 15-18). Studi yang dilakukan sebelumnya tentang perkembangan intelektual anak dipelajari lebih mendalam oleh Mentossori yang kemudian membagi masa perkembangan ke dalam empat kategori; early childhood (masa awal anak-anak) yaitu umur antara 0-6 tahun, childhood (masa anak-anak) antara 6-12 tahun, adolescence (masa remaja) antara 12-18 tahun, dan maturity (kematangan) yakni antara umur 18-24 tahun (Feez, 2010: 26-28). Walaupun demikian, tingkat perkembangan anak menunjukkan hasil yang berbedabeda tergantung dari sejauhmana aktualisasi kapasitas bawaan (inner capacity) dengan pengaruh lingkungan.

Itulah sebabnya Gardner dalam Musfiroh (2008) berpandangan bahwa tidak ada manusia yang tidak cerdas. Bahkan manusia bukan hanya memiliki tiga kecerdasan; logika-matematikaa, verbal-lingkuistik, dan visual-spasial seperti yang dikembangkan melalui teori Intellectual Question (IQ), melainkan juga kecerdasan jamak (multiple intelligences) yang mencakup delapan kecerdasan; kecerdasan verbal-linguistik, logika-matematikaa, visual-spasial, kinestetik-badaniyah, irama-musik, interpersonal, intrapersonal, dan naturalistik (Gardner, 1999 dan Amstrong, 2009), plus kecerdasan eksistensial-spiritual sebagai suatu kecerdasan yang masih dihipotesiskan karena bukti-bukti autentik belum dapat diterima sebagai hasil kajian empiris namun telah dijabarkan lebih jauh baik dalam hubungan dengan jenis teknologi yang digunakan (McKenzie, 2005) maupun dalam hubungannya dengan strategi pembelajaran berbasis multiple intelligences (Yaumi, 2013).

Kecerdasan logika-matematikaa merupakan salah satu bagian dari kecerdasan jamak yang merupakan kemampuan untuk mengkaji masalah, mengembangkan kemampuan mengoperasikan matematikaa secara logik dan analitik, dan melakukan investigasi ilmiah tentang berbagai hal (Visser, Ashton, dan Vernon, 2006). Studi yang berkenaan dengan kecerdasan logika-matematikaa dilakukan oleh Hanafin (2014) yang mengkaji tentang "Multiple Intelligences Theory, Action Research, and Teacher Professional Development: The Irish MI Project" dan salah satu temuannya menunjukkan bahwa kecerdasan logikamatematikaa dapat dibangun dengan pendekatan topik yang melibatkan proses penalaran deduktif atau melalui pertimbangan numerik. Kajian lain dilakukan oleh Supardi (2013) yang mengkaji tentang"The Contribution of Multiple Intelligence on Mathematics Learning's Success" menemukan bahwa terdapat 
tiga jenis kecerdasan yang dapat memberi dampak positif terhadap hasil belajar matematikaa termasuk (1) kecerdasan logika-matematikaa yang memberi dampak sebanyak 34,5\%, (2) visual-spasial sebesar $10,8 \%$, dan (3) keserdasan interpersonal sebanyak $7,2 \%$. Studi yang lebih khusus pada kecerdasan logika-matematikaa dilakukan oleh Suhendri (2012) yang meneliti tentang "Pengaruh Kecerdasan logicmatematika, Rasa Percaya Diri, dan Kemandirian Belajar terhadap Hasil Belajar Matematikaa" dan salah satu temuannya menunjukkan bahwa terdapat pengaruh positif dan signifikan kecerdasan logikamatematikaa terhadap hasil belajar matematikaa. Begitu pula studi yang dilakukan oleh Niroo, Nejhad, dan Haghani (2012) yang mengkaji "The effect of Gardner theory application on mathematical/logical intelligence and student's mathematical functioning relationship" menunjukkan bahwa terdapat hubungan signifikan antara hasil tes (pre-test dan post-test) dengan kecerdasan logika-matematikaa. Hal ini menunjukkan bahwa adanya pengaruh positif antara hasil belajar dengan kemampuan logika-matematikaa.

Walaupun beberapa studi tentang kecerdasan jamak khususnya kecerdasan logika-matematikaa telah menemukan adanya dampak, pengaruh, dan hubungan antara prestasi belajar dengan kecerdasan logika-matematikaa, kesulitan dalam mendeteksi, mendesain, dan mengembangkan strategi pembelajaran untuk mengembangkan kecerdasan logika-matematikaa sangat dirasakan oleh guru Taman Kanak-Kanak (TK) dan Raudhatul Athfal (RA). Berdasarkan hasil studi pendahuluan tentang kondisi objektif pelaksanaan kecerdasan jamak dalam ruang kelas Anak usia dini di Kabupaten Gowa Sulawesi Selatan menunjukkan bahwa kecerdasan logikamatematikaa sangat sulit dikembangkan dengan beberapa alasan; (1) ketiadaan instrumen yang sesuai dengan kondisi real (nyata) masing-masing sekolah, (2) kesulitan dalam pemilihan aktivitas pembelajaran yang sesuai yang langsung dapat mengarahkan anak yang memiliki kecerdasan logikamatematikaa, (3) rendahnya pemahaman teori dan konsep tentang kecerdasan logika-matematikaa, dan (4) kurangnya referensi dan pelatihan yang berkenaan langsung dengan pentingnya memahami kecerdasan jamak peserta didik khususnya kecerdasan logikamatematikaa. Permasalahan tersebut telah berimbas pada pelaksanaan aktivitas pembelajaran yang sama sekali tidak berpijak pada kecerdasan logikamatematikaa walaupun beberapa guru telah mengikuti berbagai pelatihan yang diselenggarakan baik pada tingkat lokal maupun pada tingkat regional. Selain itu, guru tidak memahami jenis kecerdasan dari masingmasing peserta didik dan tidak dapat menentukan strategi untuk mengembangkan kecerdasan tersebut. Padahal pengembangan kecerdasan jamak termasuk kecerdasan logika-matematikaa telah dipercaya dapat memberi dampak positif pada prestasi belajar peserta didik, meningkatkan motivasi intrinsik, partisipasi, dan kepercayaan diri peserta didik, serta dapat membantu pendidik dalam mendesain pembelajaran berdasarkan kebutuhan peserta didik (Johnson, 2007).

Berpijak dari beberapa masalah yang dihadapi oleh pendidik khususnya guru TK/RA seperti dijabarkan di atas memberi inspirasi kepada peneliti untuk mengkaji lebih jauh tentang desain aktivitas pembelajaran untuk mengembangkan kecerdasan logika-matematikaa bagi anak usia dini. Hasil studi ini diharapkan dapat menjadi model aktivitas pembelajaran bagi guru TK/RA, acuan dalam pengembangan kurikulum, dan menambah khazanah keilmuan khususnya dalam kaitan dengan kecerdasan logika-matematikaa sebagai bagian dari kajian kecerdasan jamak.

Secara umum, aktivitas pembelajaran dipahami sebagai praktik-praktik yang memperlakukan peserta didik bukan hanya sebagai pelaksana pembelajaran melainkan juga berperan sebagai agen tindakan kognitif yang didistribusikan antara pendidik dan peserta didik (Yaumi, 2013). Dalam pengertian sederhana, aktivitas pembelajaran merujuk pada sistem pendidikan dalam memfasilitasi peserta didik untuk menjadi agen perubahan melalui pengalaman, pengetahuan, keterampilan, dan kemampuan yang dilakukannya sendiri serta memperoleh metode untuk belajar mandiri (Kozulin Gindis, Ageyev and Miller, 2003). Fondasi teori ini didasarkan pada teori Vygotsky tentang cultural historical theory, yang mengatakan bahwa pendidikan membawa dampak pada pengembangan. Dengan demikian, yang dimaksud dengan aktivitas pembelajaran adalah aktivitas atau kegiatan apa saja dari suatu individu yang dikelola dengan maksud untuk memperbaiki keterampilan, pengetahuan, dan kompetensi (European Commission, 2006).

Kecerdasan matematika adalah kemampuan yang berkenaan dengan rangkaian alasan, mengenal pola-pola dan aturan. Kecerdasan ini merujuk pada kemampuan untuk mengekplorasi pola-pola, kategorikategori dan hubungan dengan memanipulasi objek atau simbol untuk melakukan percobaan dengan cara yang terkontrol dan teratur (Kezar, 2001). Kecerdasan matematika disebut juga kecerdasan logika dan penalaran karena merupakan dasar dalam memecahkan masalah dengan memahami prinsip-prisip yang mendasari sistem kausal atau 
dapat memanipulasi bilangan, kuantitas dan operasi (Yaumi, 2013). Kecerdasan logika-matematikaa berhubungan dengan angka-angka, pola, berpikir deduktif, induktif, dan rasional (Roop, Watson, dan Caldwell, 2001), kemampuan saintifik dan berpikir kritis (Alvis, dkk., 2008; Wilkens, 2006). Kecerdasan logika-matematikaa juga ditekankan pada kemampuan rasional, pengenalan pola abstrak, dan kemampuan untuk melakukan perhitungan yang kompleks (Motah, 2007).

Anak-anak yang memiliki kecerdasan logikamatematikaa yang tinggi sangat menyukai bermain dengan bilangan dan menghitung, suka untuk diatur, baik dalam problem-solving, mengenal pola-pola, menyukai permainan matematikaa, suka melakukan percobaan dengan cara yang logik, sangat teratur dalam tulis tangan, mempunyai kemampuan untuk berpikir abstrak, suka komputer, suka teka-teki, selalu ingin mengetahui bagaimana sesuatu itu berjalan, terarah dalam melakukan kegiatan yang berdasarkan aturan, tertarik pada pernyataan logik, suka mengumpulkan dan mengklasifikasi sesuatu, suka menyelesaikan berbagai persoalan yang membutuhkan penyelesaian yang logik, merasa lebih nyaman ketika sesuatu telah diukur, dibuat kategori, dianalisis, atau dihitung dan dijumlahkan, berpikir dengan konsep yang jelas, abstrak, tanpa katakata dan gambar. Penguatan dan pengembangan yang terarah terhadap kecerdasan matematika dapat mengarahkan karir seseorang menjadi guru matematikaa atau IPA yang memiliki kemampuan yang baik, ilmuan, insinyur, arsitek, programer komputer, pekerja konstruksi, analis anggaran, akuntan, perajut, dan aktivis yang relevan dengan ilmu-ilmu eksakta.

Pendidikan Anak Usia Dini (early childhood education) atau dalam bahasa Indonesia sering disingkat dengan PAUD menjadi suatu program yang sangat diminati belakangan ini, di samping telah menjadi trend (kecenderungan) yang mendunia juga keberpihakan pemerintah menunjukkan adanya kemauan politik yang menggembirakan bagi dunia pendidikan. Wikipedia (2014) memuat konsep anak usia dini yang merupakan tahapan awal dalam perkembangan manusia. Pada umumnya anak usia dini terdiri atas masa balita dan beberapa waktu setelahnya. Usia bermain adalah suatu sebutan yang tidak spesifik yang hampir mendekati lingkup anak usia dini. Beberapa periode perkembangan yang berkaitan dengan usia dan contoh interval yang ditetapkan adalah: bayi baru lahir (usia 0-5 minggu); bayi (usia 5 minggu - 1 tahun); balita (usia 1-4 tahun); anak prasekolah (usia 4-7 tahun); anak usia sekolah (usia 6-13 tahun); remaja (usia 13-19).

Istilah PAUD sering diberikan dengan nama yang berbeda-beda oleh beberapa lembaga. UNESCO menyebutnya sebagai early childhood care and education (ECCE), Pendidikan dan Perawatan Anak Usia Dini, Bank Dunia dan UNICEF menyebutnya sebagai Early Child Development (ECD), Pengembangan Anak Usia Dini. Walaupun namanya sedikit berbeda, tetapi pandangan mereka tentang PAUD adalah sama yaitu pendidikan yang terjadi sebelum usia wajib belajar yang dilakukan dengan berbagai bentuk seperti penitipan anak, penitipan bayi, pusat perawatan anak, taman kanak-kanak, pra-sekolah dan lembaga yang sejenis lainnya. $\mathrm{Di}$ Indonesia, PAUD merujuk pada Taman Bermain Anak, Penitipan Anak, Taman kanak-Kanak atau Raudhatul Athfal.

\section{METODE PENELITIAN}

Metode penelitian ini adalah penelitian tindakan kolaboratif (Collaborative Action Research) yang merupakan penyelidikan sistematis yang dilakukan oleh guru, administrator, konselor, atau pihak lain yang diarahkan pada proses pembelajaran dengan tujuan untuk mengumpulkan informasi tentang bagaimana mengelola sekolah secara khusus, pelaksanaan pembelajaran, dan bagaimana peserta didik belajar (Mertler, 2012). Penelitian tindakan kolaborasi melibatkan paling sedikit dua orang guru atau kelompok dari beberapa orang guru, atau orang lain yang tertarik mengarahkan penyelidikan pada isuisu tentang pelaksanaan pembelajaran dalam setting ruang kelas atau isu-isu seputar pengelolaan jurusan atau program (Ferrance, 2000). Dalam penelitian ini, kedua peneliti melibatkan 30 orang guru dari 10 Taman Kanak-Kanak/Raudhatul Athfal (TK Nurul Qalbi, TK Islam Palapa, TK Riyanti, TK Pertiwi, RA Ulil Albab I, TK Aisyiyah Panciro, TK Aisyiyah I Sungguminasa, TK Islam Palapa II, TK Mulia Jasa, TK AI Jihad) yang tersebar di seluruh Kabupaten Gowa Sulawesi Selatan.

Pemilihan peserta (informan/responden) didasari atas pertimbangan (1) telah mengikuti pelatihan tentang kecerdasan jamak (multiple Intelligence) sebelumnya, (2) lokasi sekolah sehingga penyebaran kompetensi dalam mengembangkan strategi dan aktivitas pembelajaran dapat merata, (3) direkomendasikan oleh kepala sekolah dari hasil 
kegiatan supervisi. Kolaborator dalam penelitian terdiri atas 10 orang kepala sekolah dan 5 orang Pengawas. Penelitian ini dilakukan mulai pada bulan Januari sampai dengan Agustus 2014 melalui pembiayaan DIPA UIN Alauddin Makassar. Prosedur penelitian mengadopsi model yang dikembangkan oleh Stringer (2007) yang menekankan pada tiga proses; look (melihat), think (memikirkan), dan act (menindaki) seperti terlihat pada Gambar 1.

Pertama, look merujuk pada kegiatan mengumpulkan data, membangun gambaran umum dengan mendefinisikan dan menggambarkan situasi. Pengumpulan data dapat dilakukan dengan melakukan wawancara, focus group discussion (FGD), observasi, angket, studi dokumen, rekaman, survei, dan studi literatur. Dalam penelitian ini, peneliti menggunakan FGD untuk mengumpulkan data tentang jenis aktivitas pembelajaran yang sesuai dengan kecerdasan logik-matematik, mengkaji dokumen untuk mencari sumber-sumber yang berkenaan dengan kurikulum
TK/RA, studi literatur untuk mengumpulkan bahan yang berkaitan dengan kecerdasan logik-matematik. Peneliti juga memberikan tes awal untuk mendapatkan informasi tentang konsep dan teori kecerdasan jamak. Selain itu, angket untuk memvalidasi dan mengevaluasi keberterimaan aktivitas pembelajaran yang didesain.

Kedua, think, data kualitatif yang dikumpulkan kemudian dianalisis dan diberi interpretasi dengan mengidentifikasi konsep kunci, menyaring, mengategorisasi, memberi kode, atau mereduksi, menyajikan, memverifikasi, dan mengambil kesimpulan. Sedangkan data kuantitatif dihitung, dikalkulasi, dan diukur berdasarkan kriteria atau indikator yang ada. Ketiga, act, merujuk pada menyelesaikan masalah, membuat perencanaan, dan menerapkan solusi berkelanjutan. Perencanaan mencakup identifikasi prioritas tindakan dan menentukan rencana aksi, masalah yang timbul kemudian diberi solusi dengan melibatkan berbagai komponen yang ada.

\section{HASIL DAN PEMBAHASAN}

\section{Siklus Pertama: Look, Think, Act}

Pada bagian ini, peneliti menerapkan prosedur look (tahap pertama) untuk mengumpulkan data awal tentang penguasaan konsep dasar kecerdasan jamak khususnya kecerdasan logik-matematik dengan memberikan tes atau soal bentuk pilihan ganda yang terdiri atas 50 nomor. Tes diangkat dari Buku yang berjudul "Pembelajaran Berbasis Kecerdasan Jamak (Multiple Intelligences): Mengidentifikasi dan Mengembangkan Multitalenta Anak," yang juga digunakan pada pelatihan sebelumnya. Selain menggunakan tes untuk mengumpulkan data awal, peneliti juga melakukan FGD untuk mengumpulkan data tentang kondisi nyata perencanaan dan pelaksanaan pembelajaran yang berlangsung di TK/RA dengan melibatkan 30 responden dan kolaborator (kepala sekolah dan pengawas) sebagai pendamping peneliti dalam mengajukan setiap pertanyaan.

Dalam menganalisis data (tahap kedua think) tentang penguasaan konsep dasar kecerdasan jamak khususnya kecerdasan logik-matematik, peneliti menggunakan kriteria gagal (0-44); kurang (45-64); cukup (65 - 74); baik (75-89); dan sangat baik (90 100), seperti diilustrasikan pada gambar 1 .

Gambar 1 menunjukkan bahwa tidak terdapat responden yang mendapatkan skor kurang dan gagal. Namun terdapat $4(13,33 \%)$ responden yang masih menempati posisi cukup baik. Sedangkan yang sudah mendapatkan nilai baik sebanyak 15 (50\%) responden, dan sebanyak $11(36,67 \%)$ responden yang mendapat skor sangat baik. Hal ini menunjukkan bahwa peneliti bersama kolaborator memutuskan untuk tidak memberikan pelatihan dan langsung memberikan penguatan terutama yang berkenaan langsung dengan konsep kecerdasan logik-matematik. Bentuk penguatan adalah melakukan tanya jawab dan diskusi.

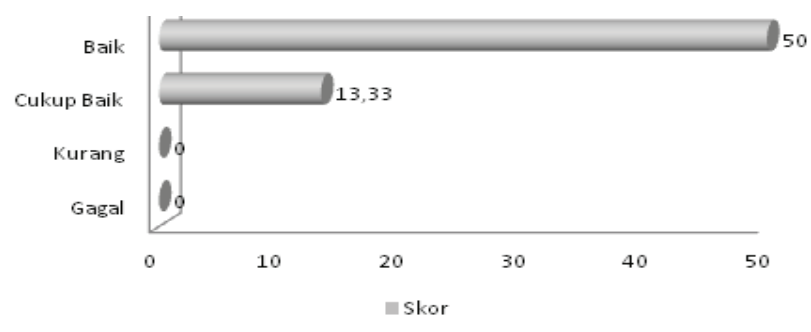

Gambar 1. Hasil tes awal

Hasil analisis data tentang kondisi nyata dalam pelaksanaan pembelajaran di TK/RA yang dikumpulkan melalui FGD dapat dijabarkan sebagai berikut: (a) aktivitas pembelajaran yang dikembangkan tidak berbasis kecerdasan jamak, khususnya kecerdasan logik-matematik; (b) tidak pernah melakukan survei kecerdasan jamak peserta didik; (c) tidak mengembangkan kecerdasan logik-matematik by design. Pengembangan kecerdasan logik-matematik dilakukan secara alamiah; (d) berbagai masalah yang dihadapi dalam mendesain dan melaksanakan pembelajaran tidak pernah didiskusikan dalam 
suatu forum guru di dalam sekolah; dan (e) tindakan penyelesaian masalah dilakukan sendiri-sendiri oleh guru yang bersangkutan.

Berdasarkan hasil tes awal terhadap penguasaan konsep dan bahan kecerdasan jamak khususnya kecerdasan logik-matematik dan hasil FGD yang dilakukan kepada 30 responden, bentuk tindakan (tahap ketiga act) yang dilakukan untuk mengatasi masalah tersebut adalah desain instrumen dan aktivitas pembelajaran untuk mendeteksi kecerdasan logik-matematik peserta didik TK/RA serta mengkaji kecenderungan perkembangan kecerdasan logikmatematik peserta didik.

a. Instrumen Kecerdasan Logik-Matematik

Peneliti menggunakan studi literatur untuk mendesain instrumen kecerdasan Logik-Matematik. Beberapa referensi yang dijadikan dasar dalam mengonstruksi setiap item instrumen kecerdasan logikmatematik adalah Connel (2005), Armstrong (2009), dan Yaumi (2013). Mengidentifikasi kecerdasan logik-matematik anak usia dini (pra-sekolah), anak usia sekolah, dan orang dewasa tentu berbeda-beda sesuai dengan tingkat kemampuan. Untuk anak usia dini, bentuk soalnya diserahkan kepada guru dan/atau orang tua untuk mendeteksinya karena mereka belum mampu membaca setiap butir instrumen yang tersedia. Walaupun demikian, anak usia dini dapat diarahkan untuk memilih gambar kegiatan yang mereka senang dan inginkan.

b. Jenis Aktivitas Pembelajaran Berbasis Kecerdasan Logik-Matematik

Mengawali kegiatan desain aktivitas pembelajaran berbasis kecerdasan jamak, peneliti membagikan angket yang berisi 27 jenis aktivitas pembelajaran kepada 30 responden dan meminta mereka untuk menyeleksi beberapa jenis aktivitas yang pernah diterapkan atau yang memungkinkan untuk diterapkan berdasarkan karakteristik peserta didik, tujuan pembelajaran, dan jenis tema yang disajikan. Adapun jenis aktivitas pembelajaran yang dipercaya cocok untuk mengembangkan kecerdasan logik-matematik adalah berpikir kritis (critical thinking), melakukan eksperimen, menggunakan pertanyaan Sokrates (Socratic questioning), menyelesaikan masalah (problem solving), menganalisis (analysing), membuat penjabaran, membuat simbol-simbol abstrak, membuat pola-pola, membuat kalkulasi, membuat kategorisasi, berpikir rasional (rational thinking), mengelasifikasi, membuat alasan, membandingkan, berpikir ilmiah (scientific thinking), membuat urutan/ rangkaian, mengartikan kode-kode, melakukan analisis statistik, membuat silogisme (jika.., maka..), melakukan sintesis, membuat rumus-rumus, mengatur batas waktu, membuat graphic organizer, membuat diagram ven, melakukan permainan logik, menulis masalah, dan bermain angka.

Setelah data dikumpulkan dan dianalisis, maka jenis aktivitas pembelajaran yang pernah dilakukan dan yang memungkinkan untuk diterapkan di dalam kelas untuk mengembangkan kecerdasan logikmatematik secara berurutan adalah sebagai berikut.

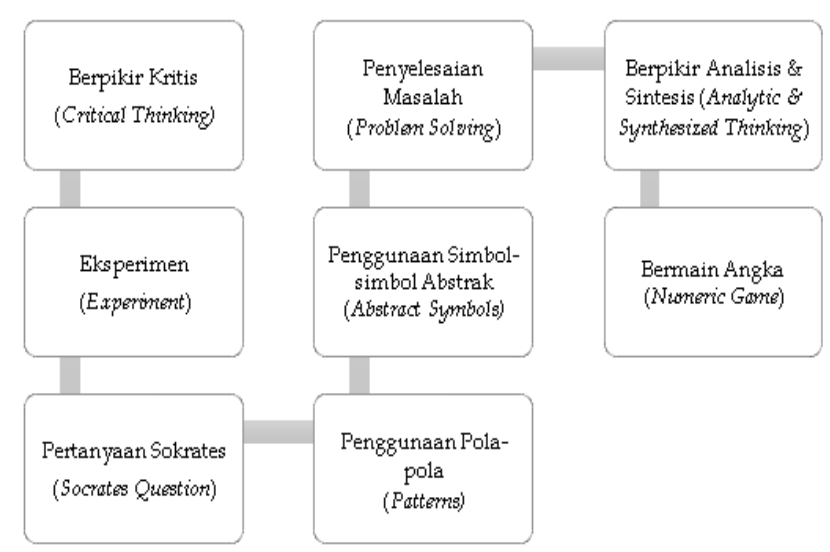

Gambar 2. Aktivitas pembelajaran berbasis kecerdasan logik-matematik.

Gambar 2 di atas memperlihatkan bahwa aktivitas pembelajaran yang dianggap cocok untuk diterapkan pada TK/RA untuk mengembangkan kecerdasan logik-matematik adalah berpikir kritis (critical thinking), bereksperimen, pertanyaan Sokrates, penyelesaian masalah, membuat simbol-simbol abstrak, membuat pola-pola, mengembangkan cara perpikir analitis dan sintesis, bermain angka. Aktivitas pembelajaran ini dipandang sebagai aktivitas yang perlu didesain dan dikembangkan.

Instrumen kecerdasan logik-matematik yang dikembangkan di atas diintegrasikan dalam ruang kelas untuk mengidentifikasi, mengenal, dan menemukan jenis kecerdasan yang dimiliki peserta didik. Begitu pula dengan delapan jenis aktivitas diterapkan berdasarkan pola penerapan yang dilakukan oleh masing-masing pendidik. Hasil dari penerapan kedua bentuk tindakan tersebut dapat ditelaah lebih jauh pada siklus kedua di bawah ini.

\section{Siklus Kedua: Look, Think, Act}

Sebelum diberi tindakan lebih lanjut untuk mengatasi persoalan yang dihadapi pada siklus kedua, perlu diawali dengan kegiatan pengumpulan data (Look) yang terkait dengan penggunaan instrumen kecerdasan logik-matematik dan strategi pembelajaran yang dikembangkan. Data dikumpulkan melalui studi dokumen dan pengamatan langsung (observasi). Studi 
dokumen digunakan untuk mengkaji berbagai kegiatan yang telah didokumentasikan seperti hasil kegiatan identifikasi kecerdasan logik-matematik peserta didik pada masing-masing kelas di sekolah yang dibina oleh para responden. Sedangkan pengamatan langsung untuk melihat pelaksanaan pembelajaran dengan menggunakan strategi pembelajaran berbasis kecerdasan logik-matematik.

Data yang berhasil dikumpulkan, kemudian dianalisis secara kuantitatif dan kualitatif. Data tentang skor kecerdasan logik-matematik yang diperoleh melalui dokumen, dihitung secara kuantitatif dengan menyajikan jumlah peserta didik yang kuat kecerdasan logik-matematik. Kecerdasan Logik-Matematik selanjutnya disingkat KLM untuk memudahkan pendeskripsiannya, seperti terlihat dalam tabel di bawah ini.

Tabel 1. Jumlah Siswa yang Memiliki Kecerdasan Logik-Matematik

\begin{tabular}{|c|l|c|c|}
\hline No & \multicolumn{1}{|c|}{ Nama Sekolah } & $\begin{array}{c}\text { Jumlah } \\
\text { Siswa }\end{array}$ & $\begin{array}{c}\text { Siswa dengan } \\
\text { KLM }\end{array}$ \\
\hline 1 & TK Nurul Qalbi & 30 & 9 \\
\hline 2 & TK Islam Palapa & 42 & 11 \\
\hline 3 & TK Riyanti & 36 & 8 \\
\hline 4 & TK Pertiwi & 33 & 9 \\
\hline 5 & RA Ulil Albab I & 40 & 13 \\
\hline 6 & $\begin{array}{l}\text { TK Aisyiyah I S. } \\
\text { Minasa }\end{array}$ & 45 & 12 \\
\hline 7 & TK Aisyiyah Panciro & 54 & 15 \\
\hline 8 & TK Islam Palapa II & 21 & 5 \\
\hline 9 & TK Mulia Jasa & 34 & 8 \\
\hline 10 & TK Al Jihad & 38 & 10 \\
\hline
\end{tabular}

Tabel 1 di atas menunjukkan bahwa jumlah peserta didik yang memiliki kecerdasan logikmatematik yang paling tinggi dimiliki oleh anak RA Ulil Albab I dengan skor rata-rata mencapai 33\%, dan skor yang terrendah dicapai oleh anak-anak yang berada di TK Riyanti yang mendapatkan skor rata-rata $22 \%$. Sedangkan skor rata-rata keseluruhan mencapai $27,5 \%$. Dengan melihat skor rata-rata tersebut menunjukkan angka yang relatif tinggi untuk kecerdasan logik-matematik. Dengan demikian, penerapan strategi berbasis kecerdasan logikmatematik mutlak sangat diperlukan.

Data tentang pelaksanaan pembelajaran yang menggunakan delapan jenis aktivitas seperti dijabarkan di atas menunjukkan hasil yang berbedabeda. Berdasarkan hasil observasi yang dilakukan oleh peneliti bersama dengan kolaborator menunjukkan bahwa terdapat tiga jenis aktivitas berbasis kecerdasan logik-matematik yang telah dilakukan, yaitu pertanyaan sokrates, penyelesaian masalah, dan bermain angka. Sedangkan untuk lima jenis aktivitas lainnya belum dijalankan. Dengan demikian dapat disimpulkan bahwa: (a) aktivitas pembelajaran yang dilaksanakan telah mengadopsi tiga jenis kecerdasan logik-matematik; (b) telah melakukan survei kecerdasan logik-matermatik peserta didik; (c) mulai mengembangkan kecerdasan logik-matematik by design; (d) berbagai masalah yang dihadapi dalam mendesain dan melaksanakan pembelajaran belum didiskusikan dalam suatu forum guru di dalam sekolah; (e) tindakan penyelesaian masalah masih dilakukan sendiri-sendiri oleh guru yang bersangkutan; dan (f) ketika dilakukan FGD kembali kepada 30 responden, belum dilaksanakan semua jenis aktivitas pembelajaran berbasis kecerdasan logik-matematik sebagaimana telah didesain bersama dengan alasan: (1) jenis kecerdasan tersebut masih sangat kompleks sehingga sulit diimplementasikan, (2) belum dapat mengaitkan secara langsung antara jenis aktivitas pembelajaran dengan tujuan serta topik bahan pembelajaran;dan (3) belum ada contoh yang dapat dijadikan standar sehingga menyulitkan untuk diterapkan.

Berdasarkan hasil FGD tersebut dan hasil diskusi bersama kolaborator, maka jenis tindakan yang diambil untuk mengatasi permasalah seperti diungkapkan di atas adalah mendesain aktivitas dengan membuat komponen-komponen penting yang diikuti dengan contoh penerapannya.

a. Desain Aktivitas Pembelajaran Berbasis Kecerdasan Logik-Matematik

Hasil FGD yang dilakukan kepada 30 responden tentang model desain aktivitas pembelajaran berbasis kecerdasan logik-matematik mencakup konsep aktivitas pembelajaran, tujuan, bahan/alat, prosedur, dan tugas, dan penyelesaian. Tugas tersebut dihubungkan dengan topik atau pokok bahasan. Konsep berisi definisi dan teori masing-masing jenis aktivitas pembelajaran di atas. Tujuan menggambarkan sasaran yang ingin dicapai termasuk kompetensi yang dibangun melalui kegiatan pembelajaran. Bahan dan alat adalah perlengkapan, fasilitas yang diperlukan untuk dapat menerapkan aktivitas pembelajaran. Prosedur memuat tahapan-tahapan penerapan aktivitas pembelajaran mulai dari kegiatan awal, kegiatan inti, sampai dengan kegiatan penutup. Selain itu, contoh tugas juga diberikan agar pendidik (guru) dapat mengaitkan secara langsung tema bahan ajar dengan aktivitas yang digunakan. Komponen ini diakhiri dengan cara menyelesaikan tugas agar dapat dijadikan patokan dasar dalam pelaksanaan 
pembelajaran. Adapun model desain aktivitas tersebut tergambarkan dalam gambar 3 .

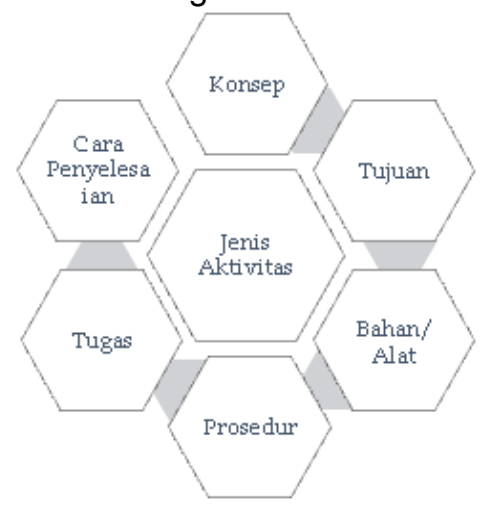

Gambar 3. Komponen desain aktivitas pembelajaran

Delapan jenis aktivitas pembelajaran berbasis kecerdasan logik-matematik kemudian didesain dengan memerhatikan enam komponen desain aktivitas pembelajaran. Setelah disusun secara bersama-sama dengan menggunakan berbagai referensi, aktivitas pembelajaran yang telah didesain dengan memasukkan unsur-unsur dalam komponen ini diterapkan dalam setting kelas masing-masing responden.

\section{Siklus Ketiga : Look, Think, Act}

Seperti pada siklus sebelumnya, kegiatan yang dilakukan di sini adalah mengumpulkan data tentang apa yang dilakukan pada siklus kedua. Pada siklus ketiga ini, peneliti menyerahkan kepada kolaborator untuk melaksanakan supervisi dengan menyediakan instrumen pengamatan. Setelah mengumpulkan data melalui pengamatan, Peneliti melaksanakan FGD kepada 30 responden dan membahas lima aspek penting, yakni pelaksanaan delapan jenis aktivitas pembelajaran, penerapan survei kecerdasan logikmatematik, penerapan hasil desain aktivitas, diskusi tentang berbagai masalah yang dihadapi, dan bentuk tindakan yang dilakukan untuk mengatasi permasalahan. Selain itu, FGD juga dilakukan untuk mengungkap dampak dari penerapan aktivitas pembelajaran terhadap pengembangan kecerdasan logik-matematik peserta didik. Untuk melihat secara komprehensif bagaimana hasil supervisi yang dilakukan kolaborator dengan kondisi nyata yang dihadapi responden setelah melaksanakan aktivitas pembelajaran berbasis kecerdasan jamak, berikut ini diuraikan secara bertahap, seperti terlihat dalam tabel 2.
Tabel 2. Hasil Pengamatan Terhadap Penerapan KLM

\begin{tabular}{|c|l|c|c|c|}
\hline \multirow{2}{*}{ No } & \multirow{2}{*}{ Bentuk Kegiatan } & \multicolumn{2}{|c|}{ Terlaksana } & \multirow{2}{*}{ Keterangan } \\
\cline { 3 - 4 } & & Ya & Tidak & \\
\hline 1 & $\begin{array}{l}\text { Survei Kecerdasan } \\
\text { logik-matematik }\end{array}$ & $\mathrm{v}$ & & \\
\hline 2 & $\begin{array}{l}\text { Penerapan 8 jenis } \\
\text { kecerdasan }\end{array}$ & $\mathrm{v}$ & & \\
\hline 3 & $\begin{array}{l}\text { Integrasi enam } \\
\text { komponen desain }\end{array}$ & $\mathrm{v}$ & & \multirow{2}{*}{$\begin{array}{c}\text { Belum } \\
\text { dilakukan }\end{array}$} \\
\hline 4 & $\begin{array}{l}\text { Diskusi tentang } \\
\text { masalah yang ada }\end{array}$ & & $\mathrm{v}$ & \\
\hline 5 & $\begin{array}{l}\text { Tindakan untuk } \\
\text { mengatasi masalah }\end{array}$ & & $\mathrm{v}$ & \multicolumn{2}{|c|}{} \\
\hline
\end{tabular}

Berdasarkan tabel 2, survei kecerdasan, penerapan delapan jenis KLM, dan integrasi enam komponen dalam aktivitas pembelajaran untuk mengembangkan KLM menunjukkan sudah terlaksana dengan baik. Adapun dua aspek lainnya seperti diskusi tentang masalah-masalah yang dihadapi di sekolah dan bentuk tindakan yang dilakukan untuk mengatasi masalah yang dihadapi belum terlaksana karena belum terdapat forum atau wadah untuk melakukannya.

Pandangan pendidik tentang peserta didik setelah penerapan aktivitas pembelajaran berbasis kecerdasan logik-matematik menunjukkan bahwa peserta didik berkembang sesuai dengan minat, bakan, dan talenta yang dimiliki. Dengan menerapkan delapan jenis aktivitas pembelajaran, peserta didik terlihat menambah gairah dan minat belajar, menunjukkan perhatian yang penuh kepada apa yang dipelajari, ada kepuasan, dan menambah kepercayaan diri mereka karena aktivitas pembelajaran tidak lagi berorientasi pada pendidik melainkan berorientasi pada peserta didik.

Pengembangan instrumen untuk mensurvei kecerdasan logik-matematik berimplikasi pada terbangunnya kesadaran baru untuk mengenal kekuatan dan kelemahan seseorang. Pengetahuan terhadap jenis kecerdasan dapat memudahkan pendidik untuk memilih strategi dan pendekatan pembelajaran sehingga arah pengembangan dapat dirancang sejak dini. Desain aktivitas pembelajaran untuk mengembangkan kecerdasan logik-matematik berimplikasi rancangan dan pelaksanaan pembelajaran berpijak pada peserta didik sehingga perkembangan intelektual, sikap, dan perilaku anak sesuai dengan bakat dan talenta yang dimiliki.

\section{PENUTUP}

\section{Kesimpulan}

Berdasarkan hasil dan pembahasan di atas, maka temuan penelitian ini dapat disimpulkan bahwa jenis aktivitas pembelajaran untuk mengembangkan kecerdasan logik-matematik anak usia dini terdiri atas delapan jenis yaitu aktivitas berpikir kritis, 
bereksperimen, pertanyaan Socrates, penyelesaian masalah, penggunaan simbol-simbol abstrak, penggunaan pola, berpikir analisis, dan bermain angka. Komponen desain aktivitas pembelajaran untuk mengembangkan kecerdasan logika-matematika mencakup uraian konsep, tujuan, bahan/alat, prosedur, tugas, dan cara penyelesaiannya.

\section{Saran}

Sebelum melaksanakan pembelajaran, pendidik seharusnya memerhatikan jenis kecerdasan jamak utamanya kecerdasan logika-matematika yang dimiliki peserta didik, mendesain pembelajaran berdasarkan jenis kecerdasan, dan menggunakan strategi dan aktivitas pembelajaran berbasis kecerdasan jamak. Khusus untuk kecerdasan logika matematika peserta didik perlu menggunakan delapan jenis aktivitas pembelajaran agar dapat menghasilkan peserta didik yang memiliki kompetensi sesuai dengan bakat, talenta, dan minat mereka. Sekolah perlu membentuk wadah sebagai forum diskusi dan sharing pengalaman sehingga jika terdapat masalah yang dihadapi akan mudah mendapat perhatian dari berbagai pihak.

\section{DAFTAR PUSTAKA}

Alvis, T., dkk. (2008). The best of multiple intelligences activities from teacher created Resources. Westminster, CA: Teacher Created Resources, Inc.

Armstrong, T. (2009). Multiple intelligences in the classroom. Alexandria, Virginia: ASCD.

Connell, J. D. (2005). Brain-based strategies to reach every learner: Surveys, questionnaires, and checklists that help you identify students' strengths - plus engaging brain-based lessons and activities. New York: Scholastic Inc.

European Commission. (2006). Classification of learning activities manual. Luxembourg: Eurostat.

Fees, S. (2010). Montessori and early childhood. Los Angeles: Sage Publications.

Ferrance, E. (2000). Action research. Providence: Brown University Press.

Gardnerm, H. (1999). Intelligence reframed: Multiple intelligences for 21st century. New York: Basic Books.

Hanafin, J. (2014). "Multiple intelligences theory, action research, and teacher professional development: The irish MI project". Australian Journal of Teacher Education, 39(4), 126-142.

Johnson, M. (2007). An extended literature review: The effect of multiple intelligences on elementary student performance. California: School of Education Dominican University of California.

Kezar. (2001). "Theory of multiple intelligences: Implications for higher education". Innovative Higher Education.Vol. 26, No. 2, Winter 2001.

Kozulin, A., dkk. (2003). Vigotsky's educational theory in cultural context. Cambridge: Cambridge University Press.

McKenzie, W. (2005). Multiple intelligences and instructional technology. Eugene, Oregon: Publishing Book of International Society for
Technology in Education.

Mertler, C.A. (2012). Action research: Improving schools and empowering educators. Los Angeles: Sage Publication.

Motah, M. (2007). "Study of the Influence of Multiple Intelligences and the use of Soft Skills in Project Write-up among IT and Non-IT Students: A Research Paper". Proceedings of the 2007 Informing Science and IT Education Joint Conference. Diunduh tanggal 12 November, 2014 dari http:// proceedings.informingscience.org/InSITE2007/ InSITE07p071-083Mota430.pdf.

Musfiroh, T. (2008). Pengembangan kecerdasan majemuk. Jakarta: Penerbit Universitas Terbuka.

Niroo, M., Nejhad, Gholamreza H, \& Haghani, Mahmoud. (2012). "The effect of Gardner theory application on mathematical/logical intelligence and student's mathematical functioning relationship". Procedia-Social and Behavioral Sciences, 47, $2169-2175$.

Piaget, J. (1965). The origin of intelligence in children. New York: International University Press, Inc.

Roop, S., Watson, K., \& Kelly Caldwell, (2001). Many ways to learn: Month-by-month activities to develop multiple intelligences. Parsippany: Pearson Learning.

Semiawan, C.R., \& Frieda Mangunsong, (2010). Keluarbiasaan ganda: Mengeksplorasi, mengenal, mengidentifikasi, dan menanganinya. Jakarta: Kencana Prenadamedia Group.

Singer, D.G., \& Tracey A. Revenson, (1996). A Piaget primer how a child thinks. New York: Penguin Group.

Stringer, E.T. (2007). Action research. Third Edition. London: Sage Publications.

Supardi U. S. (2013). "The contribution of multiple intelligence on mathematics learning's success". 
The International Journal Of Social Sciences, Volume 15, No. 1, 45-55.

Visser, B.A., Ashton, M.C., \& Vernon, P.A. (2006). "Beyond g: Putting multiple intelligences theory to the test". Intelligence, 34, 487-502.

Wikipedia. (2014). Early childhood. Diunduh tanggal
12 November 2014 dari http://en.wikipedia.org/ wiki/Early_childhood.

Yaumi, M. \& Ibrahim, N. (2013). Pembelajaran berbasis kecerdasan jamak (Multiple Intelligences): Mengidentifikasi dan mengembangkan multitalenta anak. Jakarta: Kencana Prenadamedia Group. 